(c) American Dairy Science Association, 2004.

\title{
Lactation Performance of Holstein Cows Fed Fescue, Orchardgrass, or Alfalfa Silage
}

\author{
D. J. R. Cherney, ${ }^{1}$ J. H. Cherney, ${ }^{2}$ and L. E. Chase ${ }^{1}$ \\ ${ }^{1}$ Department of Animal Science and ${ }^{2}$ Department of Crop and Soil Sciences, \\ Cornell University, Ithaca, NY 14853
}

\begin{abstract}
Perennial grasses are increasingly being used as an integral part of nutrient management plans, but fescue (Festuca arundinacea Schreb.) is often overlooked because of perceived intake problems. A 30-d study was conducted to evaluate the lactation performance of cows fed a fescue silage-based total mixed ration (TMR) compared with orchardgrass (Dactylis glomerata L.) and alfalfa (Medicago sativa L.) silage-based TMR, when forages are harvested at recommended neutral detergent fiber (NDF) levels. Holstein cows (body weight $[\mathrm{BW}]=627 \pm 66.0 \mathrm{~kg}$, milk yield $=40.9 \pm 6.93 \mathrm{~kg} / \mathrm{d}$, parity $=2.6 \pm 1.44$, days in milk $=152 \pm 24.5$ ) were randomly assigned to treatment. Statistical design was a randomized complete block with 10 cows per treatment. The 5 treatments consisted of TMR using firstcutting alfalfa, and first- and second-cutting orchardgrass and tall fescue silage. Diets were formulated to provide $0.95 \%$ of $\mathrm{BW}$ as forage NDF and contained approximately $18 \% \mathrm{CP}$ and $1.6 \mathrm{mcal} / \mathrm{kg}$. This resulted in diets of about $30 \% \mathrm{NDF}$; for a $612-\mathrm{kg}$ cow, approximately $5.8 \mathrm{~kg} / \mathrm{d}$ of forage NDF was fed. Second-cutting, grass-based TMR had lower intake than alfalfa and first-cutting forage TMR. Cows consuming second-cutting orchardgrass had lower milk production than did cows consuming other forage TMR. Cows fed fescue TMR had higher milk production than those fed orchardgrass. Indigestible residues were higher, and NDF digestibilities were lower, in second-cutting forages vs. first-cutting forages, likely contributing to the differences observed in intake and resulting differences in milk production. Dairy cows consumed the first-cutting fescue TMR readily and performed as well as those on alfalfa or first-cutting, orchardgrass-based TMR in terms of lactation performance, but fescue and orchardgrass rations will require more concentrate in the ration than alfalfa.
\end{abstract}

(Key words: dry matter intake, grass, NDF digestibility)

Received January 31, 2003.

Accepted January 30, 2004.

Corresponding author: D. J. R. Cherney; e-mail: djc6@cornell.edu.
Abbreviation key: ADL = acid detergent lignin, NSC $=$ nonstructural carbohydrates .

\section{INTRODUCTION}

The agronomic yield potential of tall fescue (Festuca arundinacea Schreb.) was $>20 \%$ higher than orchardgrass (Dactylis glomerata L.) in a New York study (Cherney et al., 2002b). In Indiana grass trials from 1994 to 1996, tall fescue yields were 34\% higher than orchardgrass (Kuhn and Johnson, 1997). Despite high yield potential, there are lingering concerns about fescue's quality for dairy cattle, in part because of the major problems associated with old endophyte-infected varieties (Baxter et al., 1985; Strahan et al., 1987).

Most studies that fed fescue to dairy cattle in the past compared the feeding of endophyte-free tall fescue to endophyte-infected tall fescue varieties. Little information is available to compare endophyte-free tall fescue forage with other perennial grasses or alfalfa (Medicago sativa L.) directly. Casler et al. (1998) observed that orchardgrass was higher in apparent intake than tall fescue for the same level of forage availability in a study evaluating grass species for management-intensive grazing. In that study, animals were allowed to choose between species. It is not clear from these results whether animals would find fescue acceptable if it were the only forage available. In another study, Fisher et al. (1993) compared fescue and orchardgrass silages fed to lactating dairy cows. They concluded that tall fescue silage was comparable to orchardgrass in supporting milk production and superior to orchardgrass in terms of palatability. It should be noted that the tall fescue in this study was lower in NDF and higher in protein than the orchardgrass, probably accounting for its superior performance. In a third study, Johansen and Nordang (1994) compared the feeding value of meadow fescue (Festuca pratensis Huds.) and timothy (Phleum pratense L.) silage fed to lactating cows. Those authors concluded that the feeding value of fescue and timothy silage was similar. In that study, fescue was harvested at a slightly later morphological stage than timothy. Our objectives were to evaluate intake and lactation performance of cows fed a fescue silage-based TMR com- 
pared with orchardgrass and alfalfa silage-based TMR when forages are harvested at comparable physiological maturities and chemical compositions.

\section{MATERIALS AND METHODS}

Forages consisted of first-cutting alfalfa and firstand second-cutting 'Arctic' orchardgrass and 'Select' tall fescue silage. Our goal was to produce alfalfa forage with $40 \% \mathrm{NDF}$ and grass forage at $50 \% \mathrm{NDF}$. Forages were grown and harvested on the Cornell University Dairy Teaching and Research Unit located near Harford, NY. Alfalfa was harvested the first week of June 1999 (first-cutting, late-bud to early-flowering stage); orchardgrass and fescue (first-cutting, early-boot stage) were harvested in late May 1999. Grass fields received $112 \mathrm{~kg} \mathrm{~N} / \mathrm{ha}$ applied as urea the first week of May. An additional $112 \mathrm{~kg}$ N/ha was applied after the first cutting each year. Alfalfa was fertilized with $\mathrm{P}$ and $\mathrm{K}$ according to soil test recommendations. Grasses were harvested a second time the first week of August 1999 (early-boot stage). After cutting, forages were fieldwilted, chopped, inoculated with silage inoculants (Pioneer 1174 for grass and Pioneer $11 \mathrm{H} 50$ for alfalfa, at about $17 \mathrm{~mL} / \mathrm{mt}$; Pioneer Hi-Bred International, Inc., Des Moines, IA), and ensiled by treatment in separate plastic bags (Ag-bag International Ltd., Warrenton, OR).

Mertens (1992) suggests that a maximum NDF intake of $1.2 \% \mathrm{BW} / \mathrm{d}$ can be fed without limiting milk yield potential. In our forage studies, we want to maximize forage intake without reducing milk yield. A consistent amount of forage NDF was chosen, $0.95 \% \mathrm{BW} / \mathrm{d}$, which allows comparisons among forages and generally results in a calculated dietary NDF intake approaching $1.1 \%$ when other ingredients are included. Diets were formulated to provide approximately $0.95 \%$ of $\mathrm{BW}$ as forage NDF (approximately 30\% NDF, DM basis). Diets were balanced for $\mathrm{NE}_{\mathrm{L}}(1.6$ to $1.7 \mathrm{Mcal} / \mathrm{kg})$ and $\mathrm{CP}(17.5$ to $18.0 \%$ ) with high moisture corn grain, soybean meal, and SoyPLUS (West Central Soy, Ralston, IA) and fed as TMR (Table 1). Diets were formulated with Spartan Ration Evaluator/Balancer for Dairy Cattle (1992) for a theoretical 612-kg Holstein cow 120 DIM, producing $36 \mathrm{~kg} / \mathrm{d}$ of milk (milk fat $=3.5 \%$; milk protein $=3.2 \%$ ). Dry matter intake was targeted to be $22.8 \mathrm{~kg} / \mathrm{d}$; intake of forage NDF was targeted at $5.8 \mathrm{~kg} / \mathrm{d}$. Diets met or exceeded NRC requirements (NRC, 1989).

Fifty Holstein cows $(\mathrm{BW}=627 \pm 66.0 \mathrm{~kg}$, milk yield $=$ $40.9 \pm 6.93 \mathrm{~kg} / \mathrm{d}$, parity $=2.6 \pm 1.44, \mathrm{DIM}=152 \pm$ $24.5)$ were used in this study. Cows within parity were randomly assigned to treatment. Statistical design was a randomized complete block with 10 cows per treatment. Cows were housed in individual tie stalls throughout the experiment and had free access to water throughout the trial. Cows were offered a TMR for ad libitum intake once daily $(0700 \mathrm{~h})$ to allow for $10 \%$ orts. The TMR offered and orts were recorded daily. The trial was $30 \mathrm{~d}$ in duration, and data collection began on $\mathrm{d} 1$. Feed offered and refused was sampled daily. The study had Cornell University Institutional Animal Care and Use Committee approval. All animals were used in compliance with federal, state, and local laws and regulations involving animal care and use, and the study was conducted in such a manner as to avoid unnecessary animal discomfort.

Cows were milked 3 times daily $(0800,1600$, and $0000 \mathrm{~h}$ ). Milk yield was recorded at each milking. Milk was sampled once weekly at all milkings and composited for each cow. Samples were preserved with 2bromo-2-nitropropane-1, 3 diol. Samples were analyzed for fat, total protein, MUN, lactose, and SCC at the New York DHI milk testing laboratory (Ithaca, NY; infrared analysis: Foss 605B Milko-Scan; Floss Electric, Hillelrod, Denmark). Cows were weighed weekly beginning with the onset of the trial and concluding with the cessation of the trial. Body condition scores (5-point scale where $1=$ thin to 5 = fat [Wildman et al., 1982]) were taken on the same day and time as cow weights.

Diet and dietary ingredients were sampled weekly throughout the $30 \mathrm{~d}$ of the trial for $\mathrm{DM}\left(60^{\circ} \mathrm{C}, 48 \mathrm{~h}\right)$ determination. Diet forage-to-grain ratio was then adjusted as necessary. Daily feed and ort samples were composited by week. These diet and ort samples were analyzed for $\mathrm{CP}, \mathrm{NDF}, \mathrm{ADF}$, and sulfuric acid detergent lignin (ADL). Crude protein was estimated by Kjeldahl methods for $\mathrm{N}$ concentration $(\times 6.25)$ with a copper catalyst (984.13; AOAC, 1990). Neutral detergent fiber, $\mathrm{ADF}$, and ADL were analyzed according to Van Soest et al. (1991), including $\alpha$-amylase and sodium-sulfite for NDF analysis using the ANKOM system (ANKOM Technology, Macedon, NY) for NDF and ADF. At the beginning of the trial, representative samples of silages and TMR were also analyzed by Dairy One (DHI Forage Testing Lab, Ithaca, NY) for DM, CP, ADF, NDF, soluble protein, nonstructural carbohydrates (NSC), and minerals. The NSC was calculated as NSC $=\%$ starch + \% sugar. Starch was determined using a YSI 2700 SELECT Biochemistry Analyzer (YSI Inc., Yellow Springs, OH). Sugar was determined using a watersoluble sugar method (Hall et al., 1999). The $\mathrm{NE}_{\mathrm{L}}$ was estimated using the forage $\mathrm{NE}_{\mathrm{L}}$ variable discount method of Van Soest and Fox (1992). For these samples, $\mathrm{DM}$ was determined by drying at $135^{\circ} \mathrm{C}$ for $2 \mathrm{~h}(930.15$; AOAC, 1990). Nitrogen was determined by combustion (Leco Instruments, Inc., St. Joseph, MI) (976.06; AOAC, 1990) and multiplied by 6.25 to obtain CP. Neutral detergent fiber, $\mathrm{ADF}$, and sulfuric acid lignin were ana- 
Table 1. Ingredient composition of diets (\% of DM).

\begin{tabular}{lccccc}
\hline Ingredient & Alfalfa $^{1}$ & OG1 & OG2 & FES1 & FES2 \\
\hline Forage & 62.1 & 53.5 & 51.2 & 58.9 & 48.2 \\
Corn grain, high-moisture & 34.3 & 38.2 & 34.9 & 32.7 & 30.8 \\
Soybean meal & 0 & 0 & 0 & 0 & 9.2 \\
SoyPLUS & 2.35 & 5.1 & 11.6 & 5.5 & 9.2 \\
All-Phos Mineral $^{2}$ & 0.75 & 0.90 & 0.9 & 0.75 & 0.75 \\
TM Salt $^{3}$ & 0.50 & 0.64 & 0.60 & 0.55 & 0.55 \\
Limestone $^{2}$ & 0 & 1.66 & 0.8 & 1.60 & 1.40 \\
\hline
\end{tabular}

\footnotetext{
${ }^{1}$ Alfalfa = alfalfa silage-based TMR, OG1 = first-cutting, orchardgrass silage-based TMR; OG2 = secondcutting, orchardgrass silage-based TMR; FES1 = first-cutting, fescue silage-based TMR; FES2 = secondcutting, fescue silage-based TMR.

${ }^{2}$ Round House Milling Company, Cortland, NY. Round House Guaranteed analysis per kg: CP from NPN, 56\%; Vitamin A, 173,500 USP Units; Vitamin D, 39,689 USP Units; Vitamin E, 703 IU; P, 19.0\%; K, 1\%; $\mathrm{Mg}, 3.8 \%$; S, 2.1\%; Mn, 0.30\%; Zn, 0.30\%; Fe, 1.35\%; Cu, 0.05\%; Co, 0.002\%; I, 0.008\%; and Se, $0.004 \%$.

${ }^{3} \mathrm{TM}$ Salt = trace mineral salt (Round House Milling Company, Cortland, NY). Guaranteed analysis: S $(\min ) 3.5 \%, \mathrm{Fe}(\min ) 8.00 \%, \mathrm{Zn}(\min ) 18 \%, \mathrm{Mn}(\min ) 15 \%, \mathrm{Cu}(\min ) 2 \%, \mathrm{I}(\min ) 0.2 \%$, and $\mathrm{Co}(\min ) 0.2 \%$.
}

lyzed as cited previously. Soluble protein was determined using a sodium-borate sodium phosphate buffer procedure (Licitra et al., 1996). Calcium, $\mathrm{P}, \mathrm{Mg}, \mathrm{K}, \mathrm{Na}$, $\mathrm{Fe}, \mathrm{Zn}, \mathrm{Cu}, \mathrm{Mn}$, Mo, and Co were analyzed using a Thermo Jarell Ash IRIS Advantage Inductively Coupled Plasma Radial Spectrometer (Thermo Jarell Ash, Franklin, MA). Sulfur was determined by combustion using a Leco Model SC-432 (Leco Instruments, Inc.). Chlorine was determined using potentiometric titration with $\mathrm{AgNO}_{3}$ using a Brinkmann Metrohm 716 Titrino Titration Unit with a silver electrode (Brinkmann Instruments Inc., Westbury, NY). Fermentation analysis of forage silages, $\mathrm{pH}$ and titratable acids was performed by Cumberland Valley Analytical Services (Maugansville, $\mathrm{MD}$ ).

In vitro fiber digestibility and digestion kinetics of TMR, sampled at the study's beginning, were determined according to Cherney et al. (1997), using the rumen buffer described by Marten and Barnes (1980) and using the Daisy $\mathrm{II}^{200 / 220}$ in vitro incubator and the ANKOM $^{200 / 220}$ fiber analyzer (ANKOM Technology Corp.). The buffer contained urea. Rumen fluid inoculum was obtained from a non-lactating, rumen-fistulated Holstein cow, offered a medium quality orchardgrass hay diet for ad libitum intake. Duplicate samples $(0.25 \mathrm{~g})$ were incubated for $48 \mathrm{~h}$ at $39^{\circ} \mathrm{C}$, followed by treating the undigested residue with neutral detergent solution. Incubation times for digestion kinetic determination were $0,6,9,12,24,36,48,72$, and $96 \mathrm{~h}$. Estimates for kinetic parameters of digestion were determined using a direct nonlinear least squares estimating procedure using the Marquardt option of procedure NLIN in SAS (1998). The model for kinetics of digestion was a simple first-order kinetic equation with a discrete lag time (Mertens and Loften, 1980). Data were analyzed using repeated measures analysis models in the PROC MIXED procedure in SAS, version 7.0 software (1998) according to Templeman and Douglass (1999). The following model was used:

$$
\mathrm{Y}_{\mathrm{ijk}}=\mu+\pi_{\mathrm{i}}+\varepsilon_{\mathrm{i}}
$$

where

$$
\begin{aligned}
Y_{\mathrm{i}} & =\text { the dependent variable }, \\
\mu & =\text { overall mean }, \\
\pi_{\mathrm{i}} & =\text { forage }(\mathrm{j}=1,2,3,4,5), \text { and } \\
\varepsilon_{\mathrm{i}} & =\text { residual error. }
\end{aligned}
$$

Data for the intake and production trial were also analyzed using repeated measures analysis models in the PROC MIXED procedure in SAS, version 7.0 software (SAS, 1998) according to Templeman and Douglass (1999). The covariance structure with the best fit was AR (1), which is first-order autoregressive; degrees of freedom were calculated using the Satterthwaite method. The statistical design was a continuous design with diet, week, and week $\times$ diet effects (day for milk production and intake). Week (day for intake and milk production) was repeated, and cow was considered random. Average milk production for the $10 \mathrm{~d}$ prior to the start of the study was used as a covariate. Significance was $P \leq 0.05$ unless otherwise stated. Interaction effects of cutting and species were evaluated using the TukeyKramer procedure for multiple comparisons $(P \leq 0.05)$. The following model was used:

$$
\mathrm{Y}_{\mathrm{ijk}}=\mu+\pi_{\mathrm{i}}+\delta_{\mathrm{j}}+\alpha_{\mathrm{k}}+\delta_{\mathrm{j}} \cdot \alpha_{\mathrm{k}}+\beta\left(\mathrm{X}_{\mathrm{ijk}}-\mathrm{X} . .\right)+\varepsilon_{\mathrm{ijkl}}
$$

where

$$
\begin{aligned}
\mathrm{Y}_{\mathrm{ijk}} & =\text { dependent variable }, \\
\mu & =\text { overall mean, }
\end{aligned}
$$


Table 2. Chemical analysis, $\mathrm{pH}$, and titratable acid analysis of forage silages (\% of DM, unless otherwise indicated).

\begin{tabular}{|c|c|c|c|c|c|}
\hline Item & Alfalfa $^{1}$ & OG1 & $\mathrm{OG} 2$ & FES1 & FES2 \\
\hline Acid detergent fiber & 34.7 & 32.3 & 30.3 & 30.4 & 32.7 \\
\hline $\mathrm{NDF}$ & 40.6 & 51.3 & 49.2 & 45.0 & 55.1 \\
\hline Acid detergent lignin & 5.96 & 3.01 & 6.70 & 1.78 & 4.16 \\
\hline $\mathrm{CP}$ & 24.3 & 24.7 & 18.1 & 26.4 & 16.2 \\
\hline $\mathrm{DM}, \%$ & 39.9 & 29.0 & 49.2 & 21.8 & 25.7 \\
\hline Soluble CP, \% of CP & 72 & 66 & 58 & 60 & 65 \\
\hline $\mathrm{NSC}^{2}$ & 23.6 & 15.2 & 24.4 & 20.7 & 20.1 \\
\hline $\mathrm{NE}_{\mathrm{L}}, \mathrm{Mcal} / \mathrm{kg}^{3}$ & 1.39 & 1.34 & 1.34 & 1.41 & 1.26 \\
\hline $\mathrm{pH}$ & 5.2 & 4.3 & 4.3 & 4.3 & 4.4 \\
\hline Titratable acid, $\mathrm{mEq} / \mathrm{g}$ & 2.9 & 5.6 & 4.3 & 8.3 & 4.8 \\
\hline
\end{tabular}

${ }^{1}$ Alfalfa = alfalfa silage, OG1 = first-cutting orchardgrass silage, OG2 = second-cutting orchardgrass silage, FES1 = first-cutting fescue silage, and FES2 = second-cutting fescue silage.

${ }^{2} \mathrm{NSC}=$ Nonstructural carbohydrate $=\%$ starch $+\%$ sugar.

${ }^{3}$ Net energy equation is from the forage $\mathrm{NE}_{\mathrm{L}}$ variable discount method of Van Soest and Fox (1992).

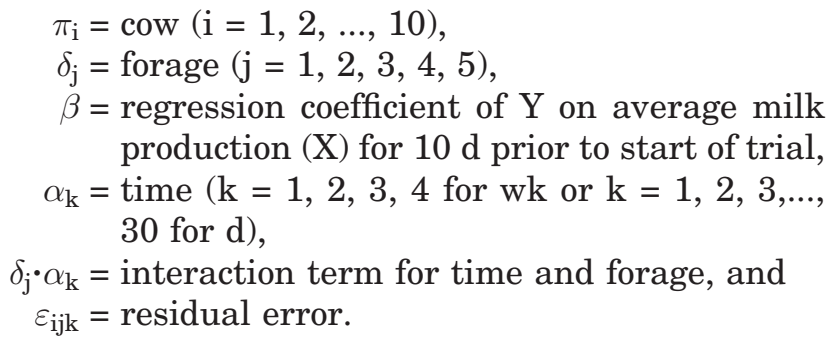

\section{RESULTS AND DISCUSSION}

Alfalfa silage was lower in NDF, but similar in $\mathrm{ADF}$ to grass silages (Table 2). Alfalfa silage ADL was higher than first-cutting grass silage ADL, but similar to second-cutting grass ADL. Crude protein content of firstcutting grass silages was similar, while second-cutting grass silages were lower in CP. Soluble CP of all forages was high $(>57 \%)$, as might be expected with the $\mathrm{CP}$ values of the forages. The low $\mathrm{pH}$ of the grass silages indicated that they were well ensiled, including the second-cutting orchardgrass, which had higher DM than would normally be desirable for proper ensiling. Second-cutting silages also had lower titratable acid than first-cutting silages, but higher titratable acid than alfalfa silage (Table 2). Addition of silage inoculants at ensiling might have facilitated the ensiling process and allowed for proper fermentation.

Chemical analyses indicated that TMR (Table 3) were on average $2.1 \%$ higher in CP than TMR formulations using individual ingredients. The NDF of consumed TMR was on average, with the exception of secondcutting grasses, $2.4 \%$ lower in formulated TMR; secondfescue TMR was on average $1.1 \%$ higher in NDF than had been formulated. Rations were initially formulated using silage samples taken from Agbags (cut at regular intervals and resealed). These samples might not have been representative of what animals consumed. In addi- tion, cows will sort concentrate components of a ration (Jonker et al., 2002), which can lead to differences in composition between consumed and offered TMR. Alfalfa-based TMR was higher in ADF than the grass silage-based TMR $(P<0.01$; Table 3$)$ because of the higher $\mathrm{ADF}$ of the alfalfa silage compared with the grass silages and because of the fact that alfalfa silage made up a greater portion of the TMR than did the grass silages (Table 1). Second-cutting, grass-based TMR were higher in $\mathrm{ADF}$ and NDF than first-cutting, grass-based TMR. Alfalfa-based TMR was higher in ADL than grasses, and second-cutting, grass-based TMR were higher in ADL than first-cutting, grassbased TMR. The year was unusually dry after the first cutting, so forage growth of the second-cutting material was delayed and lower yielding than expected. The drought also resulted in forage with a higher lignin content than probably would have occurred during a less stressful period (Van Soest, 1994). The TMR were only analyzed once at the beginning of the trial for soluble CP, NSC, $\mathrm{NE}_{\mathrm{L}}$, and macrominerals. The NSC of the TMR were similar, with the exception that the second-cutting orchardgrass appeared slighty lower than the other TMR. Potassium concentration in the orchardgrass silage TMR was less than NRC (2001) recommendations. In this range (approximately 0.8 to $0.9 \%$ of DM), some studies have shown an impact on intake and milk production (Sanchez et al., 1994a,b), and others have not reported an impact of this level of $\mathrm{K}$ on intake or milk production (Dennis and Hemken, 1978). Concentrations of other minerals met requirements.

With the exception of milk true protein concentration and BW (data not shown), all time effects were significant (Table 4). Time $\times$ forage interactions also were significant for all variables, with the exception of milk 
Table 3. Chemical analysis of TMR consumed (\% of DM, unless otherwise indicated). ${ }^{1}$

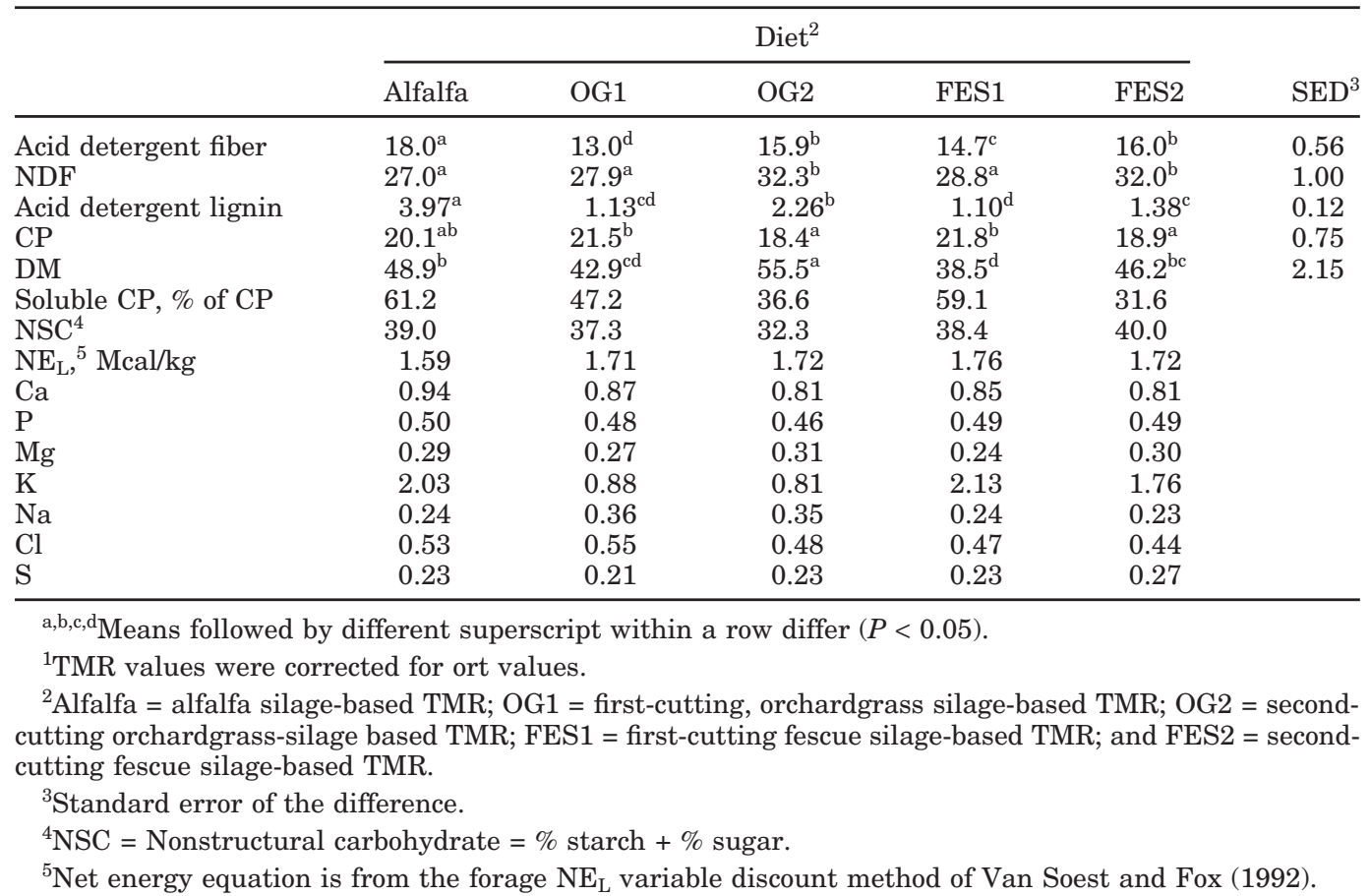

lactose concentration and BCS (data not shown). Where meaningful, time and forage $\times$ time interactions are discussed subsequently. The covariate, average milk production for the $10 \mathrm{~d}$ prior to the start of the trial, was not significant $(P>0.05)$ for any variable except milk production per day (Table 4 ).

Table 4. Least square means for intake, digestibility, milk yield, and the composition and yield of milk components.

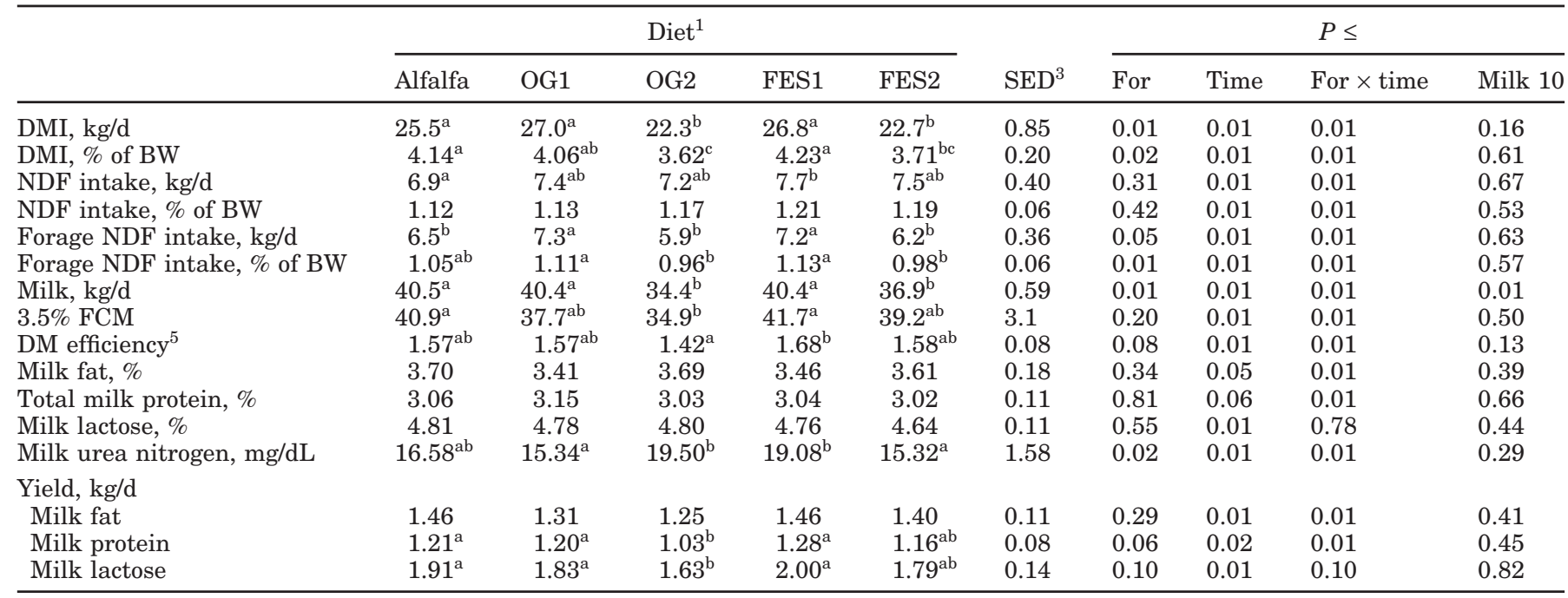

a,b,c,d Means followed by different superscripts within a row differ $(P<0.05)$.

${ }^{1}$ Alfalfa = alfalfa silage-based TMR; OG1 = first-cutting, orchardgrass silage-based TMR; OG2 = second-cutting, orchardgrass silage-based TMR; FES1 = first-cutting fescue silage-based TMR; and FES2 = second-cutting, fescue silage-based TMR.

${ }^{2}$ Contrast compares effect of alfalfa vs. grass-based TMR (contrast 1), orchardgrass vs. fescue TMR (contrast 2), and first-cutting, grassbased TMR vs. second-cutting, grass-based TMR (contrast 3).

${ }^{3}$ Standard error of the difference.

${ }^{4}$ Probability that forage (For), time, forage $\times$ time (for $\times$ time) interaction, and the covariate (milk average $10 \mathrm{~d}$ prior to start of trial; Milk10) are significant.

${ }^{5} \mathrm{DM}$ efficiency $=\mathrm{kg}$ milk/kg DMI. 


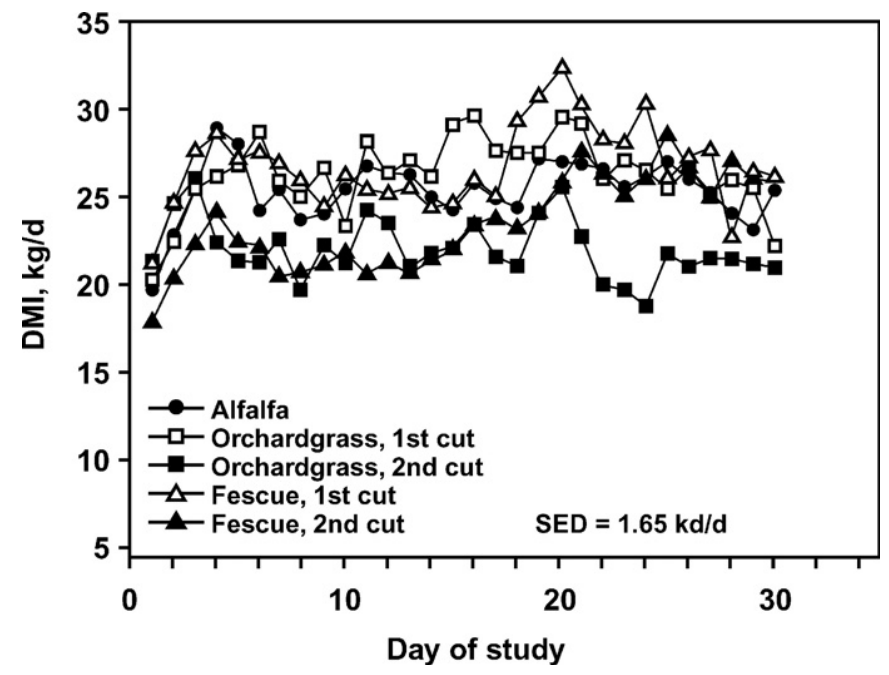

Figure 1. Dry matter intake during the trial as influenced by forage treatment.

Second-cutting grass-based TMR had lower intake than alfalfa and first-cutting forages on a $\mathrm{kg} / \mathrm{d}$ basis (Table 4) Second-cutting grass-based TMR also had numerically lower intake on as a percentage of BW (Table 4) than alfalfa and first-cutting forages, although the difference was not significant between cows fed firstcutting orchardgrass TMR and those fed second-cutting fescue TMR. Although there was day-to-day variation among treatment means (Figure 1), which accounted for time $\times$ forage interactions, intake of second-cutting orchardgrass after the first $3 \mathrm{~d}$ was always numerically lower than alfalfa and first-cutting grasses. Dry matter intake was also lower for second-cutting fescue than alfalfa and first-cutting grasses until $21 \mathrm{~d}$ into the trial. The DM value of second-cutting fescue used for ration formulation was changed on $\mathrm{d} 21$ so that the TMR better reflected the correct forage to concentrate ratio. This adjustment resulted in an increase in intake. It is likely that the higher NDF of consumed second-cutting TMR reduced intake of these TMR and reduced their intake in relation to alfalfa and first-cutting silage TMR. Perennial grass forage generally contains more NDF than legume forage, resulting in lower DMI and consequently lower production when fed as the major source of energy (Mertens, 1994). Aston et al. (1994) observed that cows ate more alfalfa silage than perennial ryegrass silage when silage was fed as the sole source of energy and protein, but not when concentrates were included in the diet at $3,6,9$, or $12 \mathrm{~kg}$ of concentrate/ d. Cherney et al. (2002a) also observed that DMI were similar between alfalfa and orchardgrass-based TMR, formulated to contain similar levels of energy, protein, and NDF from forage, when ADF of forages were similar. They also observed that cows fed early-cut orchardgrass-based TMR had higher DMI than those fed late-cut orchardgrass (Cherney et al., 2002a). Secondcut forages were not harvested later than first-cut forages in terms of physiological maturity in this study, but second-cut grasses had higher lignin (Table 1), resulting in higher indigestible residue in the second-cut grasses (Table 5). Potentially digestible fiber was higher in first-cutting orchardgrass-based TMR than in second-cut orchardgrass-based TMR (Table 5). Alfalfa had lower digestibility than first-cutting grasses (Table 5), but cows fed alfalfa did not have lower intake or production. Although not measured in this study, alfalfa is

Table 5. Silages and TMR NDF digestion kinetics.

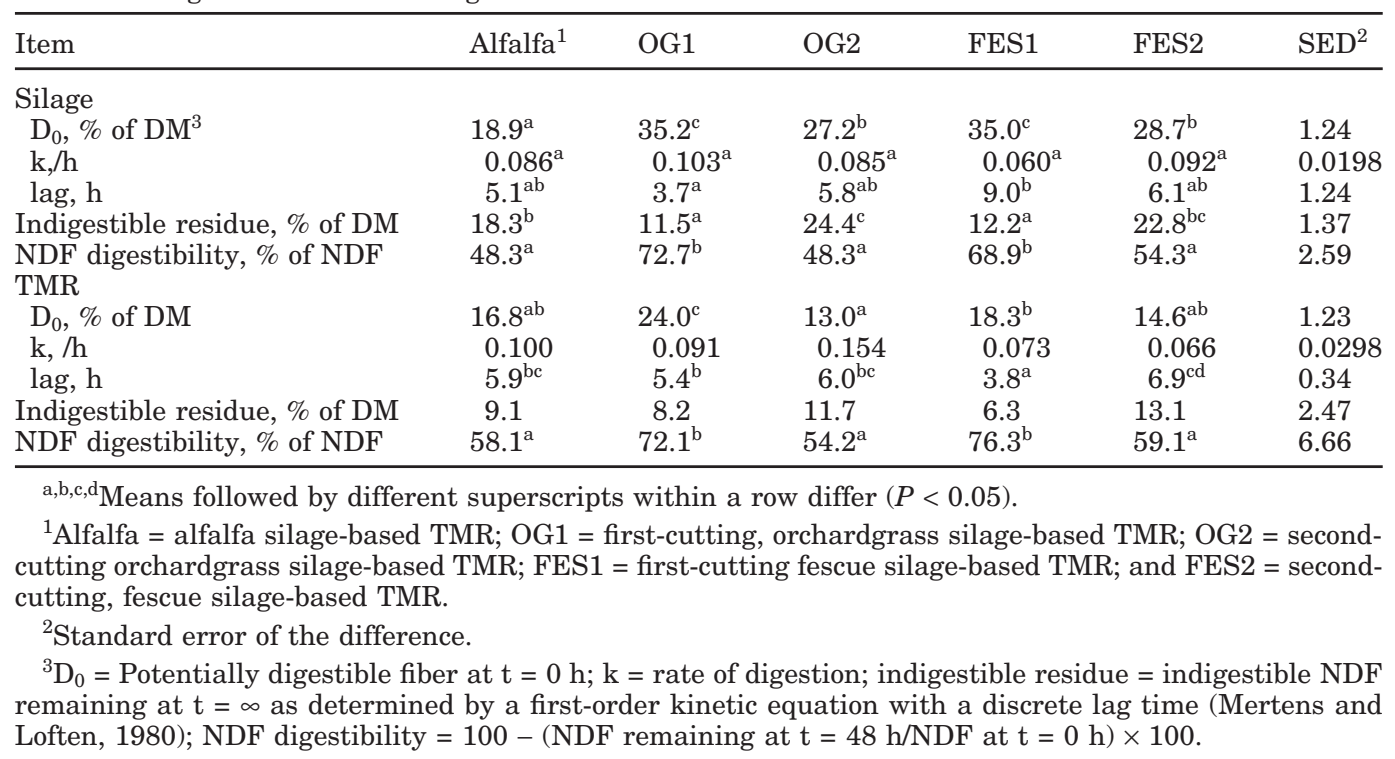


reported to have higher rates of passage than grasses (Van Soest, 1994), possibly accounting for the differences observed in this study. Cows fed second-cutting TMR were consuming higher NDF-based diets, which undoubtedly affected intake. However, animals fed these second-cutting rations had lower total NDF intake numerically than did cows fed first-cutting rations. Higher forage NDF intake (Table 4) of cows fed firstcutting grass-based TMR over those fed second-cutting grass-based TMR is a result of higher NDF digestibility (Table 5). Cows fed alfalfa-based TMR had intermediate forage NDF intake, a result that fell between forage NDF intake of cows fed first- and second-cutting grass forage (Table 4). With the exception of second-cutting grass TMR, cows ate more forage NDF than the $0.95 \%$ of BW as forage NDF that the diets were formulated for (Table 4). Mertens (1992) suggested that most cows should be able to consume $1.1 \%$ of their BW/d as NDF, without limiting milk production, which is in close agreement to what cows fed first-cutting grasses and alfalfa in this study consumed. The lower forage NDF consumed by cows fed second-cutting grass TMR suggests that factors other than NDF alone influenced intake; correlation of DMI with NDF was $-0.41(P \leq 0.01)$. Cows fed a diet high in NDF digestibility had higher DMI than those fed a lower digestibility diet (Robinson and McQueen, 1997). Oba and Allen (1999) also reported that enhanced NDF digestibility increased DMI. In addition, Ketelaars and Tolkamp (1992) suggested that higher quality forage increased the rate of passage of indigestible fiber. This would further account for the differences in DMI observed in this study; DMI was correlated $(P \leq 0.01)$ with both digestible NDF $(\mathrm{r}=0.36)$ and indigestible residue $(\mathrm{r}=-0.46)$ (correlations were among grasses only). Despite differences in DMI, there were no differences among treatments in BW $(632 \pm$ $67.6 \mathrm{~kg})$ and BCS $(2.5 \pm 0.58)$.

Daily milk production tended to follow DMI; cows fed second-cutting silage-based TMR had significantly lower milk production than cows on other treatments. (Table 4). Milk production tended to remain relatively stable over the 30-d trial with all cows on all forages, with the exception of cows on second-cutting orchardgrass TMR (Figure 2). The NDF digestibility of second-cutting grasses was lower, and indigestible residue was higher, than that of first-cutting grasses (Table $5)$. This result was mirrored in the NDF digestibility of the TMR. Lower NDF digestibility of second-cutting grasses likely contributed to their lower intake, as discussed previously, and thus lower milk production. Milk production was correlated $(P \leq 0.01)$ with $\mathrm{NDF}(\mathrm{r}=$ $-0.23)$, digestible NDF $(r=0.18)$, and indigestible residue $(r=-0.26)$. (Correlations were among grasses only.) Second-cutting orchardgrass-based TMR had lower

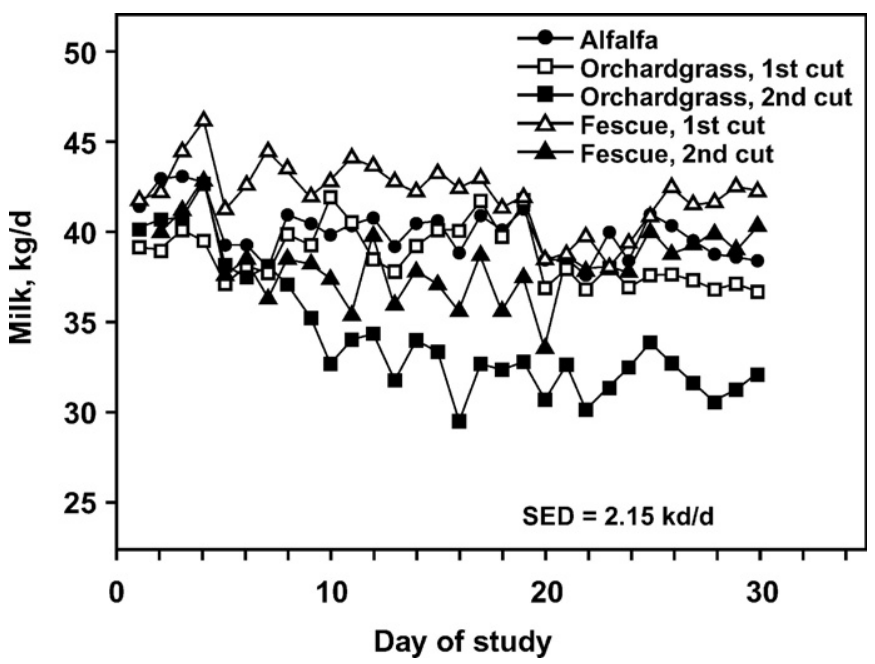

Figure 2. Milk production during the trial as influenced by forage treatment.

NSC than the other 4 TMR (Table 3). The inclusion of NSC in the range of 35 to $42 \%$ of dietary DM increases energy density and thus milk production (Lykos et al., 1997). The low NSC, in addition to high indigestible residue, probably resulted in lower milk production of cows fed second-cutting orchardgrass. Second-cutting fescue was higher in NDF, but lower in lignin, than second-cutting orchardgrass (Table 2). This resulted in a higher forage-to-concentrate ratio for the second-cutting orchardgrass TMR (Table 1). Greater levels of concentrate would increase milk production (Weiss and Shockey, 1991).

The 3.5\% FCM production was closer among treatments than uncorrected milk production, although cows fed second-cutting orchardgrass TMR still had lower FCM than cows fed alfalfa or first-cutting fescue TMR (Table 4). This was because even though differences in milk fat percentage were not significantly different, cows fed first-cutting forages had numerically lower milk fat percentage than those fed second-cutting grasses. Correlations of FCM with NDF, digestible $\mathrm{NDF}$, and indigestible residue were lower than correlations among grasses of milk and DMI with these variables: $\mathrm{r}=-0.21(P \leq 0.01), \mathrm{r}=0.10(P=0.15)$, and $\mathrm{r}=$ $-0.18(P \leq 0.01)$, respectively, for the correlation of FCM with NDF, digestible NDF, and indigestible residue. Total true milk protein and milk lactose percentage also did not vary among treatments. Phipps et al. (1987) reported that an improvement in perennial ryegrass silage quality did not improve milk fat concentration, but significantly increased milk protein concentration, and Cherney et al. (2002a) noted that improved orchardgrass quality improved milk protein. Weiss and Shockey (1991) and Orozco-Hernandez et al. (1997) did 
not report differences in milk composition when different silage types (grass or alfalfa) were fed. The improvement in quality in the present study was probably insufficient to allow for significant differences caused by treatment. Coupled with differences in milk yield, however, the trend toward difference in milk true protein did result in higher milk protein yields for cows fed firstcutting orchardgrass-based TMR vs. those fed secondcutting orchardgrass-based TMR (Table 4). Cows fed alfalfa-based TMR had similar milk protein yields compared with cows fed first-cutting grass-based TMR. Most of the differences observed could be attributed to differences in milk production.

Cows fed second-cutting orchardgrass TMR and firstcutting fescue TMR had highest MUN, those cows fed first-cutting orchardgrass and second-cutting fescue had lowest MUN, and those cows fed alfalfa TMR had intermediate MUN (Table 4). Because of lower ration $\mathrm{CP}$, lower ration soluble $\mathrm{CP}$, and higher NSC (Table 2), lower MUN from cows fed second-cutting orchardgrass TMR would have been expected in comparison with those fed first-cutting orchardgrass TMR, as it was for cows fed fescue-based TMR. Reasons for this discrepancy are not apparent.

Cows fed alfalfa had a DM efficiency that was not different from those fed the grass silages (Table 4). Cows fed fescue TMR had numerically higher DM efficiencies than those fed orchardgrass-based TMR. Higher quality forage will improve DM efficiency.

\section{CONCLUSIONS}

Lactation performance of dairy cows fed fescue silagebased TMR compared favorably with orchardgrass and alfalfa silage-based TMR when forages were harvested at recommended fiber levels. Cows fed first-cutting, late-bud to early-flowering stage alfalfa-based TMR had similar intakes and milk production as those fed grass silages, particularly those fed first-cutting grass-based TMR. Cows consuming second-cutting grass-based TMR had lower intake and milk production than did cows consuming corresponding first-cutting grassbased TMR. Differences in DMI and subsequent milk production could be attributed to differences in fiber digestibility and indigestible residue, resulting from lignin differences, as well as to differences in NSC and to higher NDF of second-cut grass TMR. This study demonstrated that dairy cows would consume fescue TMR readily and that CP levels compared favorably with well-managed alfalfa and orchardgrass. Cows fed fescue would perform as well as those cows fed alfalfabased TMR or orchardgrass-based TMR, provided that the forage is of adequate chemical composition. Both orchardgrass and fescue-based silage TMR would re- quire a higher concentrate proportion to yield similar results as alfalfa. Because all diets contained excess $\mathrm{CP}$, it is impossible to discuss the efficiency of $\mathrm{N}$ utilization of these forage sources. Further work needs to be done with these forages comparing $\mathrm{N}$ utilization.

\section{ACKNOWLEDGMENTS}

This research was supported in part by Northeast SARE Project \#LNE94-42 and in part by the Cornell University Agricultural Experiment Station federal formula funds, Project No. NYC-1277431 received from Cooperative State Research, Education, and Extension Service, U.S. Department of Agriculture. Any opinions, findings, conclusions, or recommendations expressed in this publication are those of the authors and do not necessarily reflect the view of the U.S. Department of Agriculture. This study would not have been possible without the assistance of the staff of the Cornell University Teaching and Research Facility. The assistance of Samuel Beer, Thomas Muscato, and Mary Partridge is especially appreciated.

\section{REFERENCES}

AOAC. 1990. 930.15. Moisture in animal feed. Page 69 in Official Methods of Analysis of the Association of Official Analytical Chemists. 15th ed. AOAC, Arlington, VA.

AOAC. 1990. 976.06 Protein (crude) in animal feed. p. 72 in Official Methods of Analysis of the Association of Official Analytical Chemists. 15th ed. AOAC, Arlington, VA.

AOAC. 1990. 984.13 Protein (crude) in animal feed. Copper catalyst Kjeldal method. p. 74 in Official Methods of Analysis of the Association of Official Analytical Chemists. 15th ed. AOAC, Arlington, VA.

Aston, K., C. Thomas, S. R. Daley, J. D. Suttons, and M. S. Dhanoa. 1994. Milk production from silage diets: Effects of silage characteristics and the amount of supplementary concentrate. Anim. Prod. 59:31-41.

Baxter, H. D., J. R. Owen, R. C. Buckner, R. W. Hemken, M. R. Siegel, L. P. Bush, and M. J. Montgomery. 1985. Comparison of low alkaloid tall fescue and orchardgrass for lactating Jersey cows. J. Dairy Sci. 69:1329-1336.

Casler, M. D., D. J. Undersander, C. Fredericks, D. K. Combs, and J. D. Reed. 1998. An on-farm test of perennial forage grass varieties under management intensive grazing. J. Prod. Agric. 11:92-99.

Cherney, D. J. R., J. H. Cherney, and L. E. Chase. 2002a. Performance of lactating Holstein cows as influenced by forage species and maturity, and level of inclusion. Prof. Anim. Sci. 18:316-323.

Cherney, D. J. R., J. H. Cherney, and E. A. Mikhailova. 2002b. Nitrogen utilization by orchardgrass and tall fescue from dairy manure or commercial fertilizer nitrogen. Agron. J. 94:405-412.

Cherney, D. J. R., M. J. Traxler, and J. B. Robertson. 1997. Use of Ankom fiber determination systems to determine digestibility. In Proc. NIRS Forage and Feed Testing Consortium Annual Conference, Madison, WI. NIRS Forage and Feed Testing Consortium, St. Paul, MN.

Dennis, R. J., and R. W. Hemken. 1978. Potassium requirement of dairy cows in early and mid-lactation. J. Dairy Sci. 61:757-761.

Fisher, L. J., S. Bittman, J. A. Shelford, B. D. Mason, and D. E. Hunt. 1993. A comparison of tall fescue and orchardgrass silages for lactating dairy cows. Can. J. Anim. Sci. 73:907-914.

Hall, M. B., W. H. Hoover, J. P. Jennings, and T. K. Miller Webster. 1999. A method for portioning neutral detergent soluble carbohydrates. J. Sci. Food Agric. 79:2079-2086. 
Johansen, A., and L. Nordang. 1994. A comparison between meadow fescue and timothy silage. 3. Feeding experiments with dairy cows. Norwegian J. Agric. Sci. 8:135-153.

Jonker, J. S., D. J. R. Cherney, D. G. Fox, L. E. Chase, and J. H. Cherney. 2002. Orchardgrass versus alfalfa for lactating dairy cattle: Production, digestibility, and N balance. J. Appl. Anim. Res. 21:81-92.

Ketelaars, J. J. M. H., and B. J. Tolkamp. 1992. Toward a new theory of feed intake and regulation in ruminants. 1. Causes of differences in voluntary intake: Critique of current views. Livest. Prod. Sci. 30:269-296.

Kuhn, M. E., and K. D. Johnson. 1997. Performance of orchardgrass and tall fescue in Indiana, 1994-1996. Bulletin No. B-741. Dep. Agron., Purdue Univ., West Lafayette, IN.

Licitra, G., T. M. Hernandez, and P. J. Van Soest. 1996 Standardization of procedures for nitrogen fractionation of ruminant feeds. Anim. Feed Sci. Technol. 57:347-358.

Lykos, T., G. A. Varga, and D. Casper. 1997. Varying degradation rates of total non-structural carbohydrates: Effects on ruminal fermentation, blood metabolites, and milk production and composition in high producing Holstein cows. J. Dairy Sci. 80:33413355.

Marten, G. C., and R. F. Barnes. 1980. Prediction of energy digestibility of forages with in vitro rumen fermentation and fungal enzyme systems. Pages 61-71 in Standardization of Analytical Methodology for Feeds. W. J. Pigden, C. C. Balch, and M. Graham, ed. Int. Dev. Res. Ctr., Ottawa, ON, Canada.

Mertens, D. R. 1992. Nonstructural and structural carbohydrates. Pages 219-235 in Large Dairy Herd Management. H. H. Van Horn and C. J. Wilcox, ed. Am. Dairy Sci. Assoc., Champaign, IL.

Mertens, D. R. 1994. Regulation of forage intake. Pages 450-493 in Forage Quality, Evaluation and Utilization. G. C. Fahey, Jr., ed. Am. Soc. Agron., Madison, WI.

Mertens, D. R., and J. R. Loften. 1980. The effect of starch on forage fiber digestion kinetics in vitro. J. Dairy Sci. 67:1437-1446.

National Research Council. 1989. Nutrient Requirements of Dairy Cattle. 6th rev. ed. National Academy Press, Washington, DC.

Oba, M., and M. S. Allen. 1999. Evaluation of the importance of the digestibility of neutral detergent fiber from forage: Effects on dry matter intake and milk yield of dairy cows. J. Dairy Sci. 82:589-596.
Orozco-Hernandez, J. R., G. J. Brisson, and V. Girard. 1997. Timothy grass or alfalfa silage for cows in midlactation: Effect of supplementary barley. J. Dairy Sci. 80:2876-2884.

Phipps, R. H., R. F. Weller, and J. A. Bines.1987. The influence of forage quality and concentrate level on dry matter intake and milk production of British Fresian heifers. Grass Forage Sci. 42:49-58.

Robinson, P. H., and R. E. McQueen, 1997. Influence of level of concentrate allocation and fermentability of forage fiber on chewing behavior and production of dairy cows. J. Dairy Sci. 80:681-691.

Sanchez, W. K., D. K. Beede, and M. A. Delorenzo. 1994a. Macromineral element interrelationships and lactational performance: Empirical models from a large data set. J. Dairy Sci. 77:3096-3001.

Sanchez, W. K., M. A. McGuire, and D. K. Beede. 1994b. Macromineral nutrition by heat stress interactions in dairy cattle. Review and original research. J. Dairy Sci. 77:2051-2079.

SAS Institute. 1998. The SAS System, ver. 7.0. SAS Inst., Inc., Cary, NC.

Spartan Ration Evaluator/Balancer for Dairy Cattle. 1992. Michigan State University, East Lansing, MI.

Strahan, S. R., R. W. Hemken, J. A. Jackson, Jr., R. C. Buckner, L. P. Bush, and M. R. Siegel. 1987. Performance of lactating dairy cows fed tall fescue forage. J. Dairy Sci. 70:1228-1234.

Templeman, R. J., and L. W. Douglass. 1999. NCR-170 ASAS Mixed Model Workshop. ASAS National Meetings, July 23, 1999. Am. Soc. Anim. Sci., Savoy, IL.

Van Soest, P. J. 1994. Nutritional Ecology of the Ruminant. Cornell University Press, Ithaca, NY.

Van Soest, P. J., and D. G. Fox. 1992. Discounts for net energy and protein-fifth revision. Pages 40-68 in Proc. 1992 Cornell Nutrition Conf. Feed Manufacturers, Oct. 13-15, 1992, Rochester, NY. Dep. Anim. Sci., Cornell University, Ithaca, NY.

Van Soest, P. J., J. B. Robertson, and B. A. Lewis. 1991. Methods for dietary fiber, neutral detergent fiber, and nonstarch polysaccharides in relation to animal nutrition. J. Dairy Sci. 74:35833597 .

Weiss, W. P., and W. L. Shockey. 1991. Value of orchardgrass and alfalfa silages fed with varying amounts of concentrates to dairy cows. J. Dairy Sci. 74:1933-1943.

Wildman, E. E., G. M. Jones, P. E. Wagner, R. L. Boman, H. F. Troutt, Jr., and T. N. Lesch. 1982. A dairy cow body condition scoring system and its relationship to selected production characteristics. J. Dairy Sci. 65:495-501. 